\title{
Pertussis Toxin-sensitive G Proteins Influence Nitric Oxide Synthase III Activity and Protein Levels in Rat Heart
}

\author{
Joshua M. Hare, Benjamin Kim, Nicholas A. Flavahan, Kelly M. Ricker, Xinqi Peng, Laurence Colman, Robert G. Weiss, \\ and David A. Kass \\ Department of Medicine, Cardiology Division, Johns Hopkins Medical Institutions, Baltimore, Maryland 21287-6568
}

\begin{abstract}
Inhibitory $G$ protein activity $\left(G_{i}\right)$ and nitric oxide (NO) modulate muscarinic-cholinergic (MC) inhibition of cardiac $\beta$-adrenergic inotropic responses. We hypothesized that $\mathbf{G}_{i}$ mediates MC-NO synthase (NOS) signal transduction. Isoproterenol $(0.2-0.8 \mu \mathrm{g} / \mathrm{min})$ and acetylcholine $(1 \mu \mathrm{M})$ were administered to isolated perfused rat hearts pretreated with saline (controls; $n=8$ ) or pertussis toxin (PT; $30 \mu \mathrm{g} / \mathrm{kg}$ intraperitoneally $3 \mathrm{~d}$ before study; $n=20$ ). PT abrogated in vitro ADP-ribosylation of $\mathrm{G}_{\mathrm{i}}$ protein $\alpha$ subunit(s) indicating near-total decrease in $\mathrm{G}_{\mathrm{i}}$ protein function. Isoproterenol increased peak $+\mathrm{dP} / \mathrm{dt}$ in both control (peak isoproterenol effect: $+2,589 \pm 293 \mathrm{mmHg} / \mathrm{s}, P<0.0001)$ and PT hearts $(+3,879 \pm 474 \mathrm{mmHg} / \mathrm{s}, P<0.0001)$. Acetylcholine reversed isoproterenol inotropy in controls $(108 \pm 21 \%$ reduction of $+\mathrm{dP} / \mathrm{dt}$ response, $P=\mathbf{0 . 0 0 1})$, but had no effect in PT hearts. In controls, $N^{\mathrm{G}}$-monomethyl-L-arginine $(100 \mu \mathrm{M})$ reduced basal $+\mathrm{dP} / \mathrm{dt}$, augmented isoproterenol $+\mathrm{dP} / \mathrm{dt}$ (peak effect: $+4,634 \pm 690 \mathrm{mmHg} / \mathrm{s}, P<0.0001)$, and reduced the MC inhibitory effect to $69 \pm 8 \%$ ( $P<0.03$ vs. baseline). L-arginine $(100 \mu \mathrm{M})$ had no effect in controls but in PT hearts decreased basal $+\mathrm{dP} / \mathrm{dt}$ by $1,426 \pm 456 \mathrm{mmHg} / \mathrm{s}(P<0.005)$, downward-shifted the isoproterenol concentration-effect curve, and produced a small MC inhibitory effect $(27 \pm 4 \%$ reduction, $P<0.05$ ). This enhanced response to NO substrate was associated with increased NOS III protein abundance, and a three- to fivefold increase in in vitro calciumdependent NOS activity. Neomycin $(1 \mu \mathrm{M})$ inhibition of phospholipase $\mathrm{C}$ did not reverse L-arginine enhancement of MC inhibitory effects. These data support a primary role for $G_{i}$ in $M C$ receptor signal transduction with NOS in rat heart, and demonstrate regulatory linkage between $\mathrm{G}_{\mathrm{i}}$ and NOS III protein levels. (J. Clin. Invest. 1998. 101:1424-1431.) Key words: myocardial contractility $\bullet$ muscarinic receptor • $\beta$-adrenergic receptor $\bullet$ phospholipase $\mathbf{C} \bullet \mathbf{L}$-arginine
\end{abstract}

This work was presented in part at the 69th annual scientific sessions of The American Heart Association, in New Orleans, LA, on 10-13 November 1996.

Address correspondence to Joshua M. Hare, M.D., Johns Hopkins Hospital, Cardiology Division, 600 N. Wolfe Street, Carnegie 568, Baltimore, MD 21287-6568. Phone: 410-614-4161; FAX: 410-9553478; E-mail: jhare@welchlink.welch.jhu.edu

Received for publication 23 June 1997 and accepted in revised form 20 January 1998

J. Clin. Invest.

(C) The American Society for Clinical Investigation, Inc. 0021-9738/98/03/1424/08 \$2.00

Volume 101, Number 6, March 1998, 1424-1431

http://www.jci.org

\section{Introduction}

Cholinergic stimulation of the heart acting primarily via the muscarinic cholinergic receptor $2(\mathrm{M} 2)^{1}$ attenuates $\beta$-adrenergic contractility in a fashion that is accentuated by $\beta$-adrenergic receptor stimulation (1). This is mediated in large part by $\mathrm{M} 2$ and $\beta$-adrenergic receptor coupling to adenylyl cyclase by inhibitory $\left(\mathrm{G}_{\mathrm{i}}\right)$ and stimulatory $\left(\mathrm{G}_{\mathrm{s}}\right)$ classes of $\mathrm{G}$ proteins, respectively (2). In addition to $\mathrm{G}$ protein-adenylyl cyclase regulation of inotropic responses, nitric oxide (NO) and/or cGMP have been implicated in muscarinic-cholinergic influences on myocardial contractility (3-7).

Constitutive NO synthase (NOS) activity attributed to the NOS III isoform can be detected in several cell types in the heart including microvascular and endocardial endothelial cells $(8)$, cardiac myocytes $(4,5)$, and cells of the specialized conduction system $(9,10)$. Increases in NO production from ventricular myocyte cultures can be detected in response to muscarinic agonists using a reporter cell assay (5). NO likely plays a role in muscarinic-cholinergic inhibition of $\beta$-adrenergic-stimulated chronotropy (5), inotropy (3), atrioventricular nodal conduction (9-11), and cardiac myocyte L-type calcium currents $(9,10)$, as these can be attenuated by NOS inhibition or by transcriptional downregulation of NOS III (7).

Thus, muscarinic receptor-stimulated NO production represents an alternative pathway for antagonism of $\beta$-adrenergic-stimulated inotropic responses, and it is possible that this signaling pathway may be linked to or independent of $G_{i} \cdot G$ proteins containing $\alpha$ subunits of the $\alpha_{\mathrm{i}}$ class, which can be inhibited by pertussis toxin (PT)-catalyzed ADP-ribosylation (12-16), have been implicated extensively in agonist (17-19) and shear-stress (20) coupling to NOS activation in endothelial cells. On the other hand, $\mathrm{G}_{\mathrm{i}}$ protein-independent signaling pathways are being appreciated increasingly in endothelial cells. These include regulation of NOS III intracellular compartment localization (2) and coupling via $\alpha_{\mathrm{q}} \mathrm{G}$ proteins (e.g., phospholipase C [PLC] activation) $(19,21)$.

This study had the following aims. First, we wished to assess the relative contribution of $\mathrm{G}_{\mathrm{i}}$ and NOS to cholinergic inhibition of $\beta$-adrenergic contractility. In experiments conducted in Langendorff rat hearts, we observed a marked increase in the sensitivity of PT-exposed hearts to the NOS substrate L-arginine. Accordingly, the second study aim was to determine the molecular mechanism of this effect. Our final aim was to test whether the PLC pathway contributed to cholinergic-NOS coupling independent of $\mathrm{G}_{\mathrm{i}}$.

1. Abbreviations used in this paper: $\mathrm{G}_{\mathrm{i}}$, inhibitory guanine-nucleotide binding protein; L-NAME, $N^{\mathrm{G}}$-nitro-L-arginine methyl ester; L-NMMA, $N^{\mathrm{G}}$-monomethyl-L-arginine; M2, muscarinic cholinergic receptor 2; NO, nitric oxide; NOS, NO synthase; PT, pertussis toxin; PLC, phospholipase C. 


\section{Methods}

Animal preparation. As previously described, hearts were rapidly excised from male Wistar rats $(n=47)$ premedicated with $1,000 \mathrm{U}$ intramuscular heparin and retrogradely perfused with oxygenated perfusion buffer at $37^{\circ} \mathrm{C}(22)$. A polyvinyl chloride balloon attached to PE-190 tubing balloon was placed through the left atrium and mitral valve into the left ventricle. The balloon was filled with saline to achieve a maximum isovolumic developed pressure, which typically occurred at an end-diastolic pressure of $10-15 \mathrm{mmHg}$. Hearts were perfused at a constant flow with a peristaltic pump titrated to a coronary perfusion pressure of $80 \mathrm{mmHg}$. Constant flow was used to avoid confounding alterations in contractility due to the Gregg effect (23). The perfusate contained (mmol/liter): sodium 144 , potassium 5 , calcium 1.5, bicarbonate 17.5 , magnesium 1.2 , and chloride 134 , along with $5 \mu \mathrm{g} / \mathrm{ml}$ lidocaine. This was equilibrated with a gas mixture of $95 \%$ $\mathrm{O}_{2} / 5 \% \mathrm{CO}_{2}$, resulting in a perfusate of $\mathrm{pH}$ 7.4. The hearts were placed in a heated bath to maintain the temperature at $37^{\circ} \mathrm{C}$ and paced at $390 \mathrm{bpm}$ with an electrode placed in the bath. The left ventricular pressure, the rate of change of left ventricular pressure $(\mathrm{dP} /$ $\mathrm{dt}$ ), and the mean coronary perfusion pressure were measured continuously on a physiograph (Gould Inc., Cleveland, OH) and simultaneously digitized at $1,000 \mathrm{~Hz}$. The animal protocol was approved by the Johns Hopkins University School of Medicine Animal Care and Use Committee.

Reagents. PT, L-arginine, neomycin, and $N^{\mathrm{G}}$-nitro-L-arginine methyl ester (L-NAME) were obtained from Sigma Chemical Co. (St. Louis, MO). $\mathrm{BH}_{4}$ was obtained from Alexis Corp. (San Diego, CA). $N^{\mathrm{G}}$-monomethyl-L-arginine (L-NMMA) was obtained from Calbiochem (San Diego, CA). Isoproterenol was a gift from SanofiWinthrop (New York). Acetylcholine was obtained from Iolab Pharmaceuticals (Claremont, CA). ${ }^{32} \mathrm{P}-\mathrm{NAD}$ and $\mathrm{L}-\left[{ }^{14} \mathrm{C}\right]$-arginine were obtained from New England Nuclear (Boston, MA). NOS III antibody was obtained from Transduction Laboratories (Lexington, KY).

Experimental protocols: Response to isoproterenol and acetylcholine. Rats were administered either PT $30 \mu \mathrm{g} / \mathrm{kg}$ or saline (controls) by intraperitoneal injection. $3 \mathrm{~d}$ later hearts were excised and subjected to the following series of infusions. Isolated hearts were allowed to stabilize for $15 \mathrm{~min}$, and were then administered isoproterenol $(0.2,0.4$, and $0.8 \mu \mathrm{g} / \mathrm{min})$ at rates of $0.2-0.8 \mathrm{~cm}^{3} / \mathrm{min}$ into the perfusate above the aortic cannula. At peak isoproterenol infusion, acetylcholine $\left(10^{-4} \mathrm{M}\right.$ at $0.2 \mathrm{~cm}^{3} / \mathrm{min} ; \sim 1 \%$ of coronary flow) was coinfused to achieve a final concentration of $1 \mu \mathrm{M}$ in the coronary circulation. Each infusion was continued for $5 \mathrm{~min}$ or until steady state was achieved.

Role of NO: Protocol 1. Responses to isoproterenol and acetylcholine were assessed under various conditions: saline (baseline conditions), the NOS substrate L-arginine $\left(10 \mathrm{mM}\right.$ solution at $0.2 \mathrm{~cm}^{3} /$ min or $\sim 1 \%$ of coronary flow to achieve a concentration of $100 \mu \mathrm{M}$ in the perfused circulation), and the NOS inhibitor L-NMMA (100 $\mu \mathrm{M}$ in the perfused circulation). Each of these three agents was infused for $15 \mathrm{~min}$ before and continued as a coinfusion during the next set of isoproterenol and acetylcholine infusions. After each series of isoproterenol and acetylcholine infusions, control conditions were reestablished for 10-15 min. These concentrations were based on previous in vivo $(3,24)$ and in vitro $(5)$ studies of myocardial contractility. Infusions of saline and L-arginine were performed in both PT-treated $(n=20)$ and control hearts $(n=8)$, and L-NMMA was infused in a subgroup of controls $(n=6)$.

Protocol 2. To assess whether a non- $\mathrm{G}_{\mathrm{i}}$ component of NO signaling occurred via the PLC pathway, a separate group of control $(n=$ $11)$ and PT-treated hearts $(n=8)$ underwent infusion with isoproterenol and acetylcholine during L-arginine $(100 \mu \mathrm{M})$ and then during coinfusion with L-arginine and neomycin $(1 \mu \mathrm{M})$, an inhibitor of PLC. Neomycin was selected because it attenuates the effects of acetylcholine on contractility of rat atria (21).

In vitro $P T A D P$-ribosylation. Entire hearts were frozen rapidly in liquid nitrogen after the hemodynamic protocol. Subsequently the heart tissue was homogenized and the membrane fraction was prepared. To achieve this, frozen samples of heart were pulverized in a stainless steel homogenizer, which had been cooled in dry ice. The powdered tissue was suspended in buffer $(50 \mathrm{mM}$ Tris- $\mathrm{HCl}, 2 \mathrm{mM}$ $\mathrm{MgCl}_{2}, 1 \mathrm{mM}$ EDTA, $0.1 \mathrm{mM}$ PMSF, $1 \mu \mathrm{M}$ leupeptin, $1 \mu \mathrm{M}$ antipain) (solution A), collected by centrifugation ( $700 \mathrm{~g}, 5 \mathrm{~min})$, resuspended in solution $\mathrm{A}$, and then homogenized (30 strokes, ground-glass homogenizer, $4^{\circ} \mathrm{C}$ ). The homogenate was centrifuged at $1,400 \mathrm{~g}$ for 10 $\mathrm{min}$, and the supernatant was collected and centrifuged at $40,000 \mathrm{~g}$ for $25 \mathrm{~min}$. The resulting pellet was suspended in solution A and centrifuged a second time at 40,000 $\mathrm{g}$ for $25 \mathrm{~min}$. The pellet was resuspended in solution $\mathrm{A}$ and aliquots were frozen $\left(-70^{\circ} \mathrm{C}\right)$ until used. Protein concentration was determined using a BCA protein assay kit from Pierce (Rockford, IL).

The cell membranes $(30 \mu \mathrm{g})$ were incubated for $30 \mathrm{~min}$ at $25^{\circ} \mathrm{C}$ with $(75 \mu \mathrm{l}) 10 \mathrm{mM}$ thymidine, $1 \mathrm{mM}$ ATP, $0.1 \mathrm{mM} \mathrm{GTP}, 25 \mathrm{mM}^{32} \mathrm{P}$ NAD (10 Ci/mmol), 2 mM MgCl $2,20 \mathrm{mM}$ ADP-ribose, $1 \mathrm{mM}$ EDTA, $50 \mathrm{mM} \mathrm{KPO}_{4}$, and PT $(20 \mu \mathrm{g} / \mathrm{ml}$, preactivated with $10 \mathrm{mM}$ dithiothreitol for $30 \mathrm{~min}, 32^{\circ} \mathrm{C}$ ). The reaction was terminated by the addition of $1 \mathrm{ml}$ of $10 \mathrm{mM}$ Tris-EDTA, $\mathrm{pH} 8$, and the membranes were harvested by centrifugation at $16,000 \mathrm{~g}$ for $10 \mathrm{~min}\left(4^{\circ} \mathrm{C}\right)$. Membranes were solubilized in Laemmli's buffer (3.5\% SDS, $5 \%$-mercaptoethanol, $10 \%$ glycerol, $0.0005 \%$ bromophenol blue, and $125 \mathrm{mM}$ Tris- $\mathrm{HCl}, \mathrm{pH} 6.8$ ), boiled for $5 \mathrm{~min}$, and resolved by electrophoresis through $11 \%$ polyacrylamide gels. [ $\left.{ }^{32} \mathrm{P}\right] \mathrm{ADP}$-ribosylated proteins were visualized by autoradiography at $-70^{\circ} \mathrm{C}$ with intensifying screens.

Myocyte isolation. As previously described, rat ventricular myocytes were isolated from collagenase-digested ventricular tissue (25, 26). Hearts were retrograde perfused $\left(7 \mathrm{~min}, 5 \mathrm{ml} / \mathrm{min}, 37^{\circ} \mathrm{C}\right.$ ) with a collagenase buffer containing protease in Tyrode's solution $(140 \mathrm{mM}$ $\mathrm{NaCl}, 5 \mathrm{mM} \mathrm{KCl}, 1 \mathrm{mM} \mathrm{MgCl}$, $10 \mathrm{mM}$ Hepes, $10 \mathrm{mM}$ glucose, $\mathrm{pH}$ 7.4). Ventricular tissue was finely minced in a high potassium solution (120 mM K-glutamate, $25 \mathrm{mM} \mathrm{KCl,} 1 \mathrm{mM} \mathrm{MgCl}_{2}, 10 \mathrm{mM}$ Hepes, $1 \mathrm{mM}$ EGTA, $10 \mathrm{mM}$ glucose, $\mathrm{pH}$ 7.2), and poured through a nylon mesh. The myocytes were allowed to pellet and then resuspended in the same high potassium buffer.

Western blot of NOS III protein. Western blotting was performed on total heart tissue pulverized in lysis buffer $(150 \mathrm{mM} \mathrm{NaCl}, 50 \mathrm{mM}$ Tris, pH 7.6, 1 mM EDTA, 0.1\% SDS, 1\% sodium deoxycholate, $1 \%$ Triton X-100, $1 \mathrm{mM}$ PMSF, $50 \mathrm{mM} \mathrm{NaF}, 0.5 \mathrm{mM}$ sodium orthovanadate, $1.5 \mu \mathrm{M}$ pepstatin $\mathrm{A}, 20 \mu \mathrm{M}$ leupeptin, and $2 \mu \mathrm{g} /$ liter aprotinin) and centrifuged at 13,000 rpm for $30 \mathrm{~min}$. Isolated myocytes were allowed to pellet and were resuspended in lysis buffer. Equal amounts of protein $(100 \mu \mathrm{g})$ from the supernatant were loaded and separated on $7.5 \%$ Tris-Glycine Ready Gels (Bio-Rad Laboratories, Richmond, CA) and transferred to a nitrocellulose membrane that was reversibly stained with Ponseau S. The membrane was blocked with 5\% nonfat dry milk in PBS overnight at $4^{\circ} \mathrm{C}$. Membranes were incubated with rabbit polyclonal anti-mouse NOS III antibody, 1:250 dilution in 5\% nonfat dry milk in PBS for $1 \mathrm{~h}$ at room temperature. After three washes (20 min each) with PBS/0.1\% Tween 20, the membranes were incubated for $1 \mathrm{~h}$ at room temperature with an anti-rabbit antibody (Transduction Laboratories). The membranes were exposed to film using chemiluminescence (ECL Western blotting detection reagents) for $15 \mathrm{~min}$.

Measurement of NOS activity. NOS activity was measured by the conversion of $\mathrm{L}-\left[{ }^{14} \mathrm{C}\right]$-arginine to $\mathrm{L}-\left[{ }^{14} \mathrm{C}\right]$-citrulline using a modification of the method of Bredt and Snyder (27). Finely ground, frozen heart tissue or pelleted isolated myocytes obtained from PT-treated and control rats were suspended in $3 \mathrm{ml}$ of ice-cold homogenizing buffer $(50 \mathrm{mM}$ Tris, $\mathrm{pH} 7.4$, containing $0.1 \mathrm{mM}$ EDTA, $0.1 \mathrm{mM}$ EGTA, $12 \mathrm{mM} \beta$-mercaptoethanol, and the protease inhibitors $2 \mathrm{mM}$ PMSF and $4 \mu \mathrm{M}$ leupeptin). The suspension was homogenized, centrifuged $\left(34,000 \mathrm{rpm}\right.$ for $60 \mathrm{~min}$ at $\left.5^{\circ} \mathrm{C}\right)$, and the pellet resuspended in Tris buffer (50 mM, pH 7.4) containing $330 \mathrm{nM}$ calmodulin, $10 \mu \mathrm{M}$ $\mathrm{BH}_{4}, 0.1 \mathrm{mM}$ EDTA, $0.1 \mathrm{mM}$ EGTA, $12 \mathrm{mM} \beta$-mercaptoethanol, $2 \mathrm{mM}$ PMSF, and $4 \mu \mathrm{M}$ leupeptin. Reactions were initiated by adding purified $\mathrm{L}-\left[{ }^{14} \mathrm{C}\right]$-arginine $(330 \mathrm{mCi} / \mathrm{mmol})$ to produce a $10 \mathrm{mM}$ final con- 
centration in the presence of $1 \mathrm{mM}$ NADPH, $4 \mu \mathrm{M} \mathrm{FAD}, 4 \mu \mathrm{M} \mathrm{BH}_{4}$, and $1 \mathrm{mM} \mathrm{CaCl}$. Reactions performed in duplicate were carried out for $30 \mathrm{~min}$ at room temperature, and quenched with $3 \mathrm{ml}$ ice-cold stop buffer (20 mM Hepes and $2 \mathrm{mM}$ EDTA, pH 5.5). Parallel reactions were performed in the presence of either EDTA $(2.0 \mathrm{mM})$ or L-NAME $(6 \mathrm{mM}) . \mathrm{L}-\left[{ }^{14} \mathrm{C}\right]$-citrulline was separated from the reaction mixture by cation-exchange chromatography using Dowex AG 50W-X8 resin and quantified by liquid scintillation counting. Counts were normalized for protein content (Bradford method). Total NOS activity was determined by subtracting counts in the presence of L-NAME from counts in the absence of EDTA, calcium-independent activity (presumably NOS II) was determined by subtracting L-NAME-blocked counts from counts in the presence of EDTA, and NOS III activity was determined as total NOS activity minus calcium-independent activity (calcium-dependent) (28).

Data analysis. Data are presented as mean \pm SEM. Comparisons between baseline variables in PT- and vehicle-treated hearts were performed using paired or unpaired $t$ tests, as appropriate. Cholinergic inhibitory responses (percent reduction of peak isoproterenol inotropic response due to acetylcholine) were performed with either the paired $t$ test or sign rank test, as appropriate. Concentrationeffect relationships for isoproterenol and isoproterenol plus acetylcholine were assessed using two-way ANOVA with an identification term for individual experiments (29). These concentration-effect relationships were determined individually for hearts subjected to the isoproterenol and acetylcholine infusions at baseline and during L-arginine. Post-hoc testing to assess the concentration-effect relationship and the impact of acetylcholine used the Student-Newman Keuls test. Comparisons of concentration-effect relationships before and after L-arginine or before and after L-NMMA were made using repeated measures ANOVA (29). Comparisons between PT and vehicle hearts were performed with three-way ANOVA. Statistical calculations were performed using SAS software.

\section{Results}

Effect of PT on protein ADP-ribosylation. Sarcolemmal fractions prepared from rat heart extracts were subjected to PT $\left[{ }^{32} \mathrm{P}\right]$ ADP-ribosylation. This analysis revealed a single $41-\mathrm{kD}$ band absent from hearts pretreated with PT (Fig. 1), consistent with ADP-ribosylation of the alpha subunit of $\mathrm{G}_{\mathrm{i}}$. The abolishment of the in vitro toxin-catalyzed ADP-ribosylation of $\mathrm{G}_{\mathrm{i}}$ protein $\alpha$ subunits(s) confirmed the effectiveness of the in vivo treatment.

Baseline hemodynamics. Control hearts $(n=8)$ had a peak positive $\mathrm{dP} / \mathrm{dt}$ of $5,175 \pm 289 \mathrm{mmHg} / \mathrm{s}$ and a developed pressure of $130.2 \pm 2.5 \mathrm{mmHg}$ at left ventricular end-diastolic pressure 14.4 $\pm 2.4 \mathrm{mmHg}$ (Table I). While hearts from PTtreated rats $(n=20)$ had similar developed pressure at a matched left ventricular end-diastolic pressure, baseline $+\mathrm{dP} / \mathrm{dt}$ was higher than control hearts $(7,126 \pm 425 \mathrm{mmHg} ; P=0.01$ vs. control; Table I). This increase in $\mathrm{dP} / \mathrm{dt}$ is consistent with an enhanced contractility due to removal of the effects of $G_{i}$.

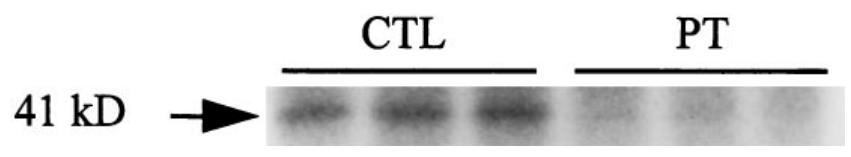

Figure 1. In vitro ADP-ribosylation of membranes prepared from whole heart. Rats were administered either saline $(C T L)$ or PT intraperitoneally $3 \mathrm{~d}$ before experiment. Membranes were prepared and subjected to PT-catalyzed ADP-ribosylation in the presence of ${ }^{32} \mathrm{P}$ NAD, resolved by PAGE and autoradiographed. Membranes from PT hearts lacked a 41-kD band corresponding to the $\alpha$ subunit of $\mathrm{G}_{\mathrm{i}}$.
Table I. Baseline Conditions

\begin{tabular}{lccc}
\hline & Baseline & L-arginine & L-NMMA \\
\hline Control & & & \\
HR (bpm) & $388 \pm 1$ & $389 \pm 1$ & $388 \pm 1$ \\
LVEDP (mmHg) & $14.4 \pm 2.4$ & $15.3 \pm 2.3$ & $14.6 \pm 2.5$ \\
LVESP (mmHg) & $144.6 \pm 3.3$ & $128.9 \pm 8.8^{\S}$ & $97.5 \pm 8.1^{\S}$ \\
LVdev (mmHg) & $130.2 \pm 2.5$ & $114 \pm 8^{\S}$ & $82.9 \pm 6.2^{\S}$ \\
Peak +dP/dt (mmHg/s) & $5175 \pm 289$ & $5052 \pm 571$ & $3453 \pm 295^{\S}$ \\
CPP $(\mathrm{mmHg})$ & $80 \pm 2$ & $75 \pm 6$ & $124 \pm 7.5^{\S}$ \\
& & & \\
PT & & & \\
HR $(\mathrm{bpm})$ & $389 \pm 1$ & $389 \pm 1$ & \\
LVEDP (mmHg) & $12.7 \pm 0.6$ & $13.9 \pm 0.9$ & \\
LVESP (mmHg) & $160.7 \pm 7.5$ & $136.1 \pm 7.4^{\ddagger}$ & \\
LVdev (mmHg) & $150 \pm 7.3$ & $122 \pm 7^{\ddagger}$ & \\
Peak $+\mathrm{dP} / \mathrm{dt}(\mathrm{mmHg} / \mathrm{s})$ & $7126 \pm 425^{*}$ & $5700 \pm 372^{\ddagger}$ & \\
CPP $(\mathrm{mmHg})$ & $78 \pm 2$ & $99.6 \pm 5^{* \ddagger}$ & \\
& & & \\
\hline
\end{tabular}

$* P=0.01$ vs. control, ${ }^{\ddagger} P<0.005$, and ${ }^{\S} P<0.05$ vs. corresponding baseline. $H R$, Heart rate; $L V E D P$, left ventricular end-diastolic pressure; $L V E S P$, left ventricular end-systolic pressure; $L V d e v$, left ventricular developed pressure; $P e a k+d P / d t$, peak rate of $L V$ pressure rise; $C P P$, coronary perfusion pressure.

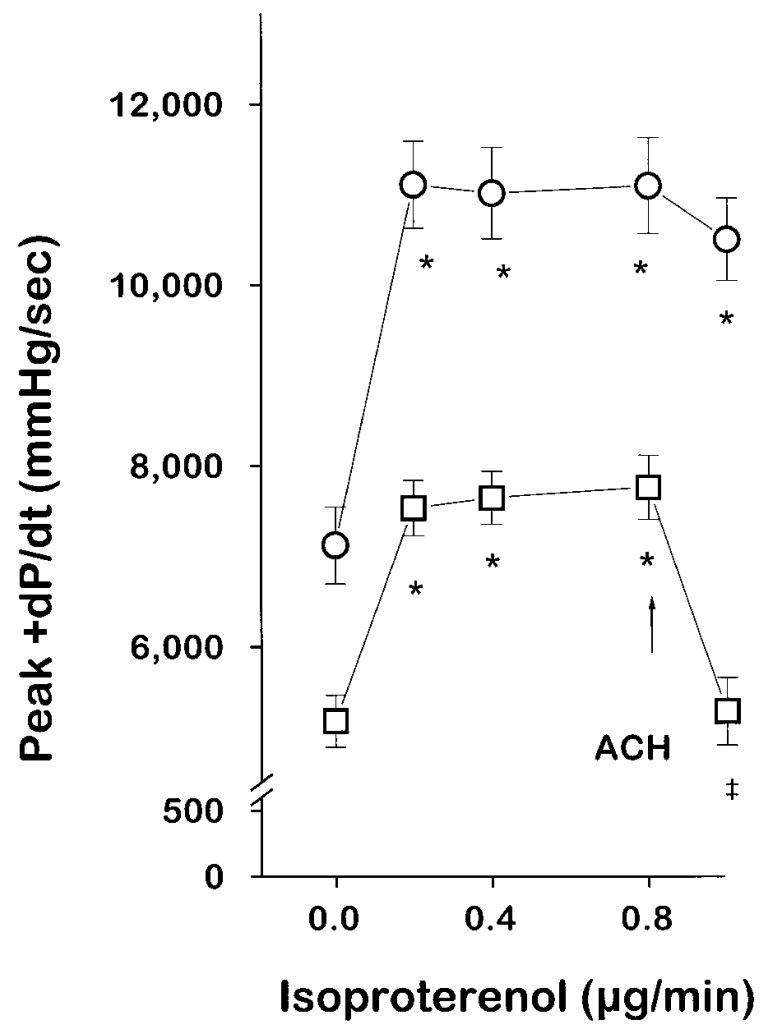

Figure 2. Responses to isoproterenol and acetylcholine in Langendorff hearts. Isoproterenol was infused at the indicated rates for $5 \mathrm{~min}$. At peak isoproterenol, acetylcholine was coinfused to achieve a $1 \mu \mathrm{M}$ concentration (arrow). Shown are the peak $+\mathrm{dP} / \mathrm{dt}$ responses in control (squares, $n=8$ ) and PT (circles, $n=20)$ hearts. Data represent mean \pm SEM. $* P<0.05$ vs. baseline, ${ }^{\ddagger} P<0.05$ vs. isoproterenol. 
Table II. Peak $+d P / d t$ Response to Isoproterenol in Control and PT Hearts

\begin{tabular}{lccc}
\hline Isoproterenol $(\mu \mathrm{g} / \mathrm{min})$ & 0.2 & 0.4 & 0.8 \\
\hline Control & & & \\
Change $+\mathrm{dP} / \mathrm{dt}$ & $2361 \pm 249$ & $2473 \pm 241$ & $2589 \pm 293$ \\
$\%$ change $+\mathrm{dP} / \mathrm{dt}$ & $47 \pm 6$ & $50 \pm 6$ & $52 \pm 7$ \\
$\mathrm{PT}$ & & & \\
Change $+\mathrm{dP} / \mathrm{dt}$ & $3989 \pm 434^{*}$ & $3893 \pm 441^{*}$ & $3879 \pm 474^{*}$ \\
$\%$ change $+\mathrm{dP} / \mathrm{dt}$ & $69 \pm 15^{*}$ & $66 \pm 14^{*}$ & $68 \pm 16^{*}$ \\
& & & \\
\hline
\end{tabular}

$* P<0.001$ vs. control (three-way ANOVA)

Effect of acetylcholine on the positive inotropic response to isoproterenol. In control rats, successive infusions of isoproterenol $0.2,0.4$, and $0.8 \mu \mathrm{g} / \mathrm{min}$ for $5 \mathrm{~min}$ each resulted in a $2,589 \pm 293 \mathrm{mmHg} / \mathrm{s}$ increase in $+\mathrm{dP} / \mathrm{dt}$ at peak isoproterenol $(P<0.0001$; ANOVA for isoproterenol effect; Fig. 2$)$. At peak isoproterenol, coinfusion of $1 \mu \mathrm{M}$ acetylcholine resulted in a reduction in $+\mathrm{dP} / \mathrm{dt}$ of $2,362 \pm 176 \mathrm{mmHg} / \mathrm{s}(108 \pm 21 \% ; P=$ 0.001; Fig. 2), confirming the effect of muscarinic receptor agonists to antagonize the positive inotropic response to $\beta$-adrenergic receptor stimulation in this model.

In PT hearts, the successive infusions of isoproterenol 0.2 , 0.4 , and $0.8 \mu \mathrm{g} / \mathrm{min}$ for $5 \mathrm{~min}$ each resulted in a 3,879 \pm 474 $\mathrm{mmHg} / \mathrm{s}$ increase in $+\mathrm{dP} / \mathrm{dt}$ at peak isoproterenol $(P<0.0001$; ANOVA for isoproterenol effect, Fig. 2). Compared with control hearts the $+\mathrm{dP} / \mathrm{dt}$ response to isoproterenol (absolute and percent increase in $+\mathrm{dP} / \mathrm{dt}$ ) was accentuated (Table II). At peak isoproterenol, coinfusion of $1 \mu \mathrm{M}$ acetylcholine resulted in a peak $+\mathrm{dP} / \mathrm{dt}$ of $10,512 \pm 460 \mathrm{mmHg} / \mathrm{s}$, which was not significantly different from that of isoproterenol alone, 11,104 \pm 530 $\mathrm{mmHg} / \mathrm{s}$. Thus, PT abolished the acetylcholine inhibition of isoproterenol responses.
Effect of NOS inhibition on cholinergic and isoproterenol responses. Inhibition of NOS has been shown both in vivo and in vitro to augment the $\beta$-adrenergic inotropic response $(5,24$, $30)$ and to attenuate cholinergic inhibition of adrenergic-stimulated contractility $(3,4)$. To determine whether these effects were present in our model, we compared the adrenergic and cholinergic inotropic effects during coinfusion of the NOS precursor L-arginine with those during the NOS inhibitor L-NMMA in control hearts. L-arginine did not affect baseline $+\mathrm{dP} / \mathrm{dt}$ (Table I), the response to isoproterenol, or the response to acetylcholine. Compared with L-arginine, L-NMMA reduced basal peak $+\mathrm{dP} / \mathrm{dt}$ to $3,453 \pm 295 \mathrm{mmHg} / \mathrm{s}(P<0.05$ vs. L-arginine, Table I). After L-NMMA, the isoproterenol increase in $+\mathrm{dP} / \mathrm{dt}$ was greater than during L-arginine both in absolute terms and in terms of a change in baseline (4,569 \pm 471 $\mathrm{mmHg} / \mathrm{s}$ at peak effect, Fig. 3, $A$ and $B$ ). Also in agreement with earlier findings, L-NMMA reduced the cholinergic inhibition from $108 \pm 21$ to $69 \pm 8 \%(P=0.03)$. Taken together, these observations demonstrate the presence of a NOS signaling pathway in the isolated rat heart.

Effect of L-arginine on basal and stimulated contractility. In contrast to controls in which L-arginine had no effect, in PT hearts the NOS substrate lowered basal $+\mathrm{dP} / \mathrm{dt}$ (Table I) and caused a parallel shift downward in the concentration-effect curve to isoproterenol (Fig. 4). Moreover, during L-arginine infusion, acetylcholine had a small but significant inhibition of the $+\mathrm{dP} / \mathrm{dt}$ response to isoproterenol; the absolute level of peak $+\mathrm{dP} / \mathrm{dt}$ during acetylcholine $(9,146 \pm 548 \mathrm{mmHg} / \mathrm{s})$ was significantly different from that of isoproterenol alone $(10,131 \pm$ $434 \mathrm{mmHg} / \mathrm{s} ; P<0.05$, Fig. 4$)$, a $27 \pm 6 \%$ reduction in the isoproterenol effect $(P<0.001)$.

NOS III protein abundance and activity. To determine a possible mechanism for the enhanced sensitivity to L-arginine in PT hearts, we performed Western blotting of NOS III protein. In total heart extracts, protein abundance appeared increased in PT hearts (Fig. $5 \mathrm{~A}$ ). The increase in protein abun-

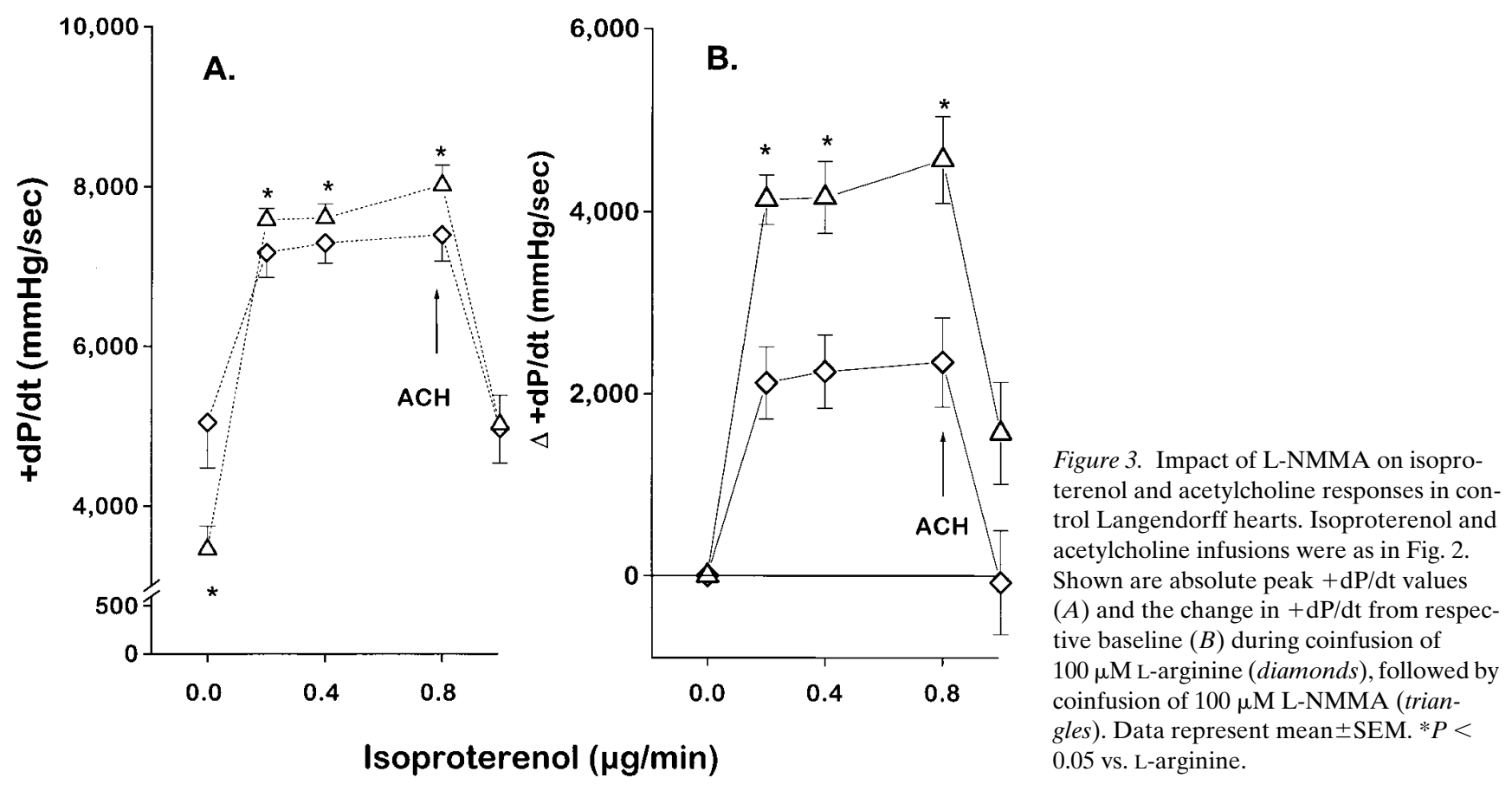




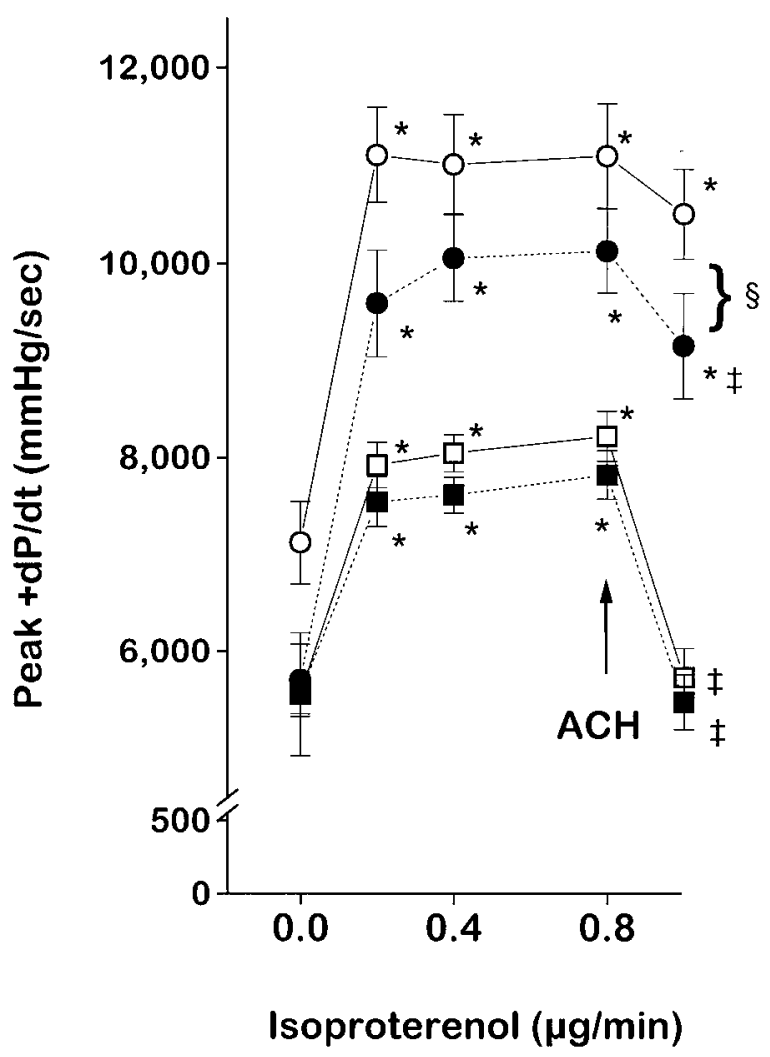

Figure 4. Effect of L-arginine on isoproterenol and acetylcholine responses in control and PT Langendorff hearts. Isoproterenol and acetylcholine infusions were as in Fig. 2. Shown are the peak $+\mathrm{dP} / \mathrm{dt}$ responses in control (squares, $n=8$ ) and PT (circles, $n=20$ ) hearts. Baseline responses are represented with open symbols and L-arginine responses with closed symbols. Data represent mean \pm SEM. $* P<$ 0.05 vs. baseline, ${ }^{\ddagger} P<0.05$ vs. isoproterenol, ${ }^{\S} P=0.0006$ by ANOVA with repeated measures for comparison of isoproterenol doseresponse curves before and after L-arginine.

dance was much more apparent when performed on protein from isolated myocytes (Fig. $5 \mathrm{~B}$ ); similar qualitative results were obtained in three to four independent samples each of control and PT hearts. Arginine-to-citrulline conversion assays demonstrated a threefold increase in NOS III activity in PT versus control total heart extracts $(3.84 \pm 1.87$ vs. $1.33 \pm 0.19$ $\mathrm{pmol} / \mathrm{mg}$ protein, $n=3$ each). Similar enhanced activity (approximately fivefold increase) was obtained from isolated myocyte protein extracts. Calcium-independent activity (NOS II) was not observed in either PT or control samples from whole heart or isolated myocytes.

Effect of neomycin on isoproterenol and acetylcholine responses. The observation that L-arginine led to a small but significant cholinergic inhibitory effect in PT hearts raised the possibility of a parallel non- $\mathrm{G}_{\mathrm{i}}$ signaling pathway. Since PLC has been implicated recently in cholinergic signaling in rat atria (21), we assessed whether a component of muscarinic receptor coupling to NOS was mediated by PLC in a non- $\mathrm{G}_{\mathrm{i}}$ pathway (i.e., $\mathrm{G}_{\mathrm{q}}$ ), and studied an additional series of control $(n=11)$ and PT hearts $(n=8)$ during L-arginine administration. As shown in Fig. 6, both the increase in peak $+\mathrm{dP} / \mathrm{dt}$ to isoproterenol and the decrease due to acetylcholine were similar before and during infusion of neomycin. In this series of experiments, during L-arginine, acetylcholine decreased the
$+\mathrm{dP} / \mathrm{dt}$ response to isoproterenol by $81 \pm 3 \%(P<0.05)$ in controls and $32 \pm 7 \%$ in PT hearts $(P<0.05)$. The degree of inhibition in PT hearts was similar in magnitude to that observed during L-arginine in the initial series of hearts.

\section{Discussion}

The present data indicate that the component of muscariniccholinergic regulation of myocardial contractility influenced by NO occurs via PT-sensitive G protein signal transduction. PT treatment not only abolished acetylcholine reversal of the inotropic response to the $\beta$-adrenergic agonist isoproterenol, but also markedly increased protein abundance and activity of NOS III, measured functionally in isolated hearts and in vitro. Increased NOS III protein and in vitro activity was evident in protein prepared from both whole heart extracts and from purified myocytes. $\mathrm{G}_{\mathrm{i}}$ and NOS III appear to be linked with regard to both signal transduction and to regulation of protein levels.

Several in vivo (3) and in vitro $(4,5,7,21)$ studies have demonstrated that NO is involved in muscarinic-cholinergic signaling in the heart. The NO pathway has been shown to influence both muscarinic inhibition of contractility $(3,4,21)$, heart rate (5), and atrioventricular nodal conduction $(9,10)$. Patch-clamp preparations have shown that these actions likely occur by regulation of the L-type calcium current $\left(I_{c a}\right)(9,10)$. NO influences on contractility are likely mediated by stimulation of soluble guanylyl cyclase to increase production of cGMP, which rises with muscarinic-cholinergic stimulation of the heart (31-35). cGMP production influences the initiation of myocyte contraction by inhibiting cAMP stimulated $\mathrm{I}_{\mathrm{Ca}}(6$, $36,37)$, and may also decrease myofilament calcium responsiveness (38).

The coupling between cardiac muscarinic receptor activation and NOS has not been elucidated previously, and we considered several potential pathways. First, it seemed most likely that this link could be mediated by inhibitory G proteins. Muscarinic attenuation of $\beta$-adrenergic contractility in the heart can be largely attributed to $\mathrm{G}_{\mathrm{i}}(12-15)$, and in endothelial cells $\mathrm{G}_{\mathrm{i}}$ can be demonstrated to mediate signal transduction between several cell-surface receptors (including the muscarinic receptor) $(17,18,20)$ and NOS activity $(19,20,39-42)$. Our observation that a cholinergic-inhibitory effect could be essen-

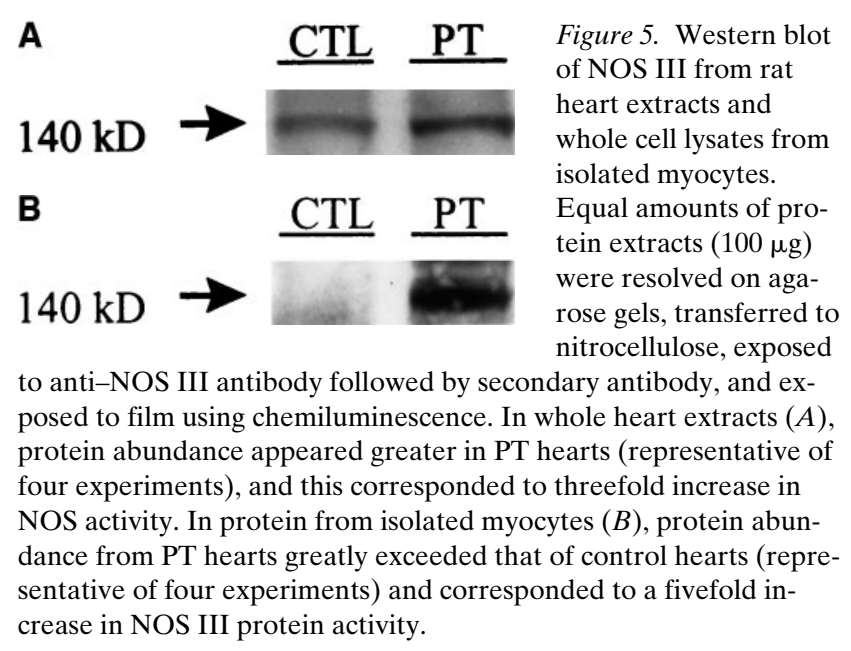




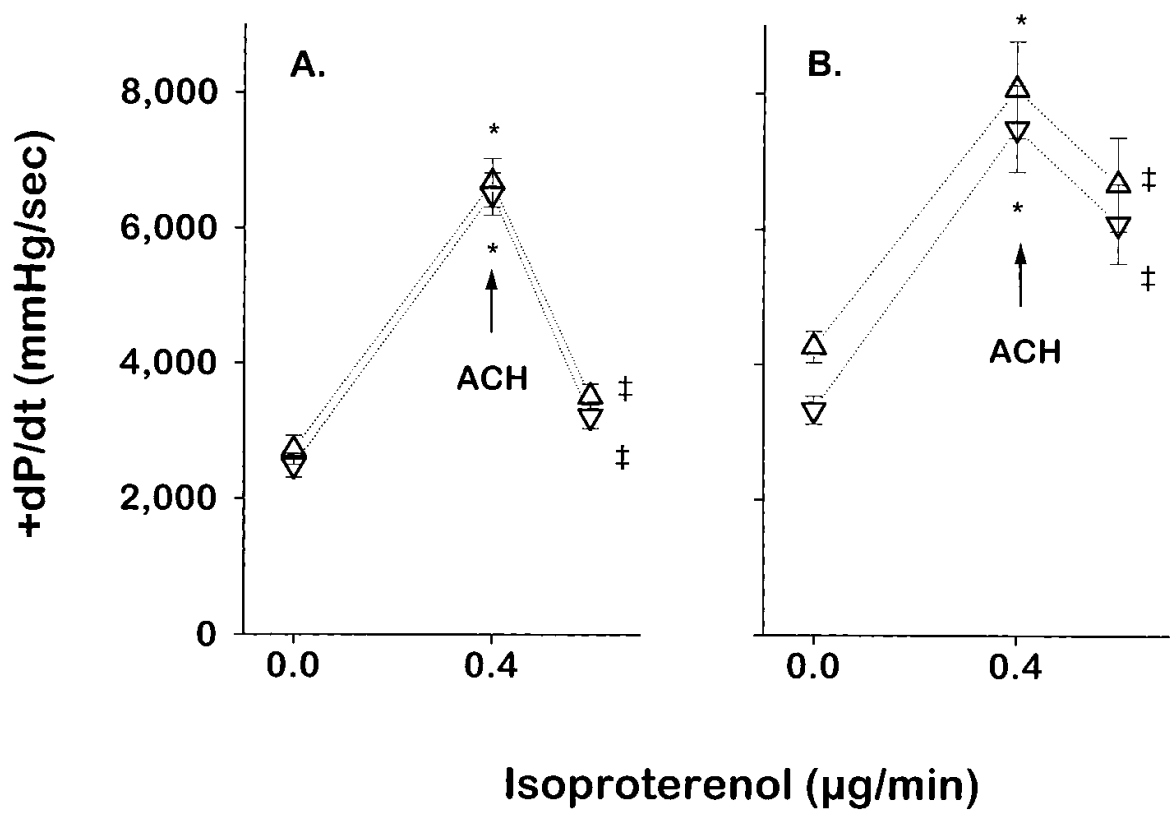

Figure 6. Impact of neomycin on isoproterenol and acetylcholine responses in control and PT-treated Langendorff hearts. Isoproterenol and acetylcholine infusions were as in Fig. 2. Shown are the peak $+\mathrm{dP} / \mathrm{dt}$ responses in control $(A, n=11)$ and PT hearts $(B, n=8)$ during coinfusion of $100 \mu \mathrm{M} \mathrm{L}$-arginine (up triangles) followed by coinfusion of $100 \mu \mathrm{M}$ L-arginine $+1 \mu \mathrm{M}$ neomycin (down triangles). Data represent mean \pm SEM. $* P<0.05$ vs. baseline, ${ }^{\ddagger} P<0.05$ vs. isoproterenol. tially eliminated by PT indicated a primary role for $\mathrm{G}_{\mathrm{i}}$ in postmuscarinic receptor signaling.

We also observed a marked increase in NOS III protein abundance, in vitro calcium-dependent NOS activity, and an enhanced sensitivity to the NOS substrate L-arginine in PT hearts. The latter was reflected by a reduction in basal peak $+\mathrm{dP} / \mathrm{dt}$, a parallel downward shift in the isoproterenol concentration-effect curve, and by a small but significant restoration of cholinergic inhibition. Whether constitutive NO activity in the heart that influences myocardial function derives from myocytes themselves or from adjacent cell-types (i.e., endothelial cells) has been a topic of intense interest. Balligand and colleagues have shown that cardiac myocytes contain an endogenous NOS III that is involved in parasympathetic signaling (4). Therefore, we also assessed the impact of PT treatment on NOS III protein abundance and activity in isolated cardiac myocytes. Our finding that PT elevated NOS III protein and activity in isolated myocytes confirms this upregulation in the cells responsible for contractile activity, but does not exclude a possible additional contribution of paracrine endothelial NOS activity. This increase in NOS III protein and activity is consistent with a compensatory upregulation and supports a controlling link between $\mathrm{G}_{\mathrm{i}}$ and NOS III protein level.

The influence of $\mathrm{G}_{\mathrm{i}}$ on NOS III protein level could occur by either increasing protein production or reducing degradation. $\mathrm{G}_{\mathrm{i}}$ suppression causing an increase in cAMP production likely would not play a role in increasing NOS III protein since elevating cAMP has been shown to have an opposite effect, that of decreasing NOS III gene expression (7). Future study will be required to elucidate the precise relationship between $G_{i}$ and NOS III protein abundance.

The presence of an enhanced L-arginine NO pathway in PT hearts permitted further study of NO signaling. In PT hearts, L-arginine restored a small but significant cholinergic inhibition of isoproterenol $\mathrm{dP} / \mathrm{dt}$ responses. Therefore, we sought to assess the mechanism of this minor pathway, and hypothesized that PLC, which has been implicated in cholinergic influences over contractility (21), might be involved in cholinergic NO signal transduction. PLC signaling usually occurs by receptor coupling via $G_{q}$ which is not affected by PT (16). Sterin-Borda et al. have shown recently in rat atrial myocytes that the inhibitor of PLC, neomycin, led to a rightward shift in the concentration-effect curve of carbachol on the rate of force generation (21). This inhibitory effect was of a magnitude similar to that achieved with L-NMMA. Accordingly, using neomycin we tested whether the PLC pathway could influence the L-arginine-stimulated NO pathway in PT hearts. As neomycin did not affect either the isoproterenol or acetylcholine contractile effects, in either control or PT hearts, a non- $\mathrm{G}_{\mathrm{i}}$ PLC pathway is unlikely to play a role in cholinergic inhibition of $\beta$-adrenergic contractility.

A third putative signaling link is control of NOS intracellular localization. NOS III by virtue of posttranslational myristolation and palmitoylation is a membrane-bound enzyme and, in both endothelial cells and cardiac myocytes (2), has been shown to be localized to caveolae, which are plasmalemmal microdomains involved in regulation of signal transduction pathways. Interestingly, the cardiac M2 receptor has also been shown recently to localize to caveolae when stimulated with carbachol (43), further suggesting a role for caveolae in M2NOS signal transduction. In endothelial cells, stimulation with agonists such as bradykinin activate NOS III in association with phosphorylation and depalmitoylation which result in translocation of the enzyme to the cytosol (44). More directly, tyrosine phosphorylation (45) has been shown to be important in shear-stress-stimulated NO production in endothelial cells. Thus, cellular localization may represent a control mechanism for enzyme activation. The present data suggest that subcellular compartment localization, if important in muscarinic-cholinergic NOS signal transduction, also involves $\mathrm{G}_{\mathrm{i}}$.

In our model we observed suppression of peak $+\mathrm{dP} / \mathrm{dt}$ by L-NMMA but augmented responses to isoproterenol. Studies in humans (46) and dogs (47) measuring cardiac output responses were the first to suggest that NOS inhibition may have a negative inotropic effect. This has remained controversial, however, since other studies have shown no effect of NOS in- 
hibition on resting peak $+\mathrm{dP} / \mathrm{dt}(5,24,30)$. This discrepancy may be explainable by observations that NO may have a biphasic effect on contractility and L-type calcium currents (6), having positive inotropic effects at low physiologic doses, and negative inotropic effects at higher doses (48). With regard to the L-type calcium current, opposite effects of NO can also be observed based on redox milieu; Campbell and colleagues have reported that direct $S$-nitrosylation of the L-type Cachannel increased calcium transients in a fashion that depended on whether thiol moieties were oxidized or reduced (49). Thus, in control hearts, L-NMMA alone likely acted to remove tonic NO production which may have supported resting contractility. Despite this suppression of resting contractility, L-NMMA augmented $\beta$-adrenergic contractility, a phenomenon previously observed in isolated myocytes (5), dogs (24), and humans (30). On the other hand, L-arginine had no effect in control hearts but suppressed resting and $\beta$-adrenergic contractility in PT hearts, consistent with production of supraphysiologic NO levels due to NOS III overexpression (48).

Several technical issues merit discussion. First, our isolated heart preparation was carried out to eliminate factors that could confound measurements of myocardial contractility. Throughout the study, isovolumic measurements were obtained at a fixed preload volume. Further, fixed coronary flow was used to avoid altering contractility due to the Gregg effect (23). Finally, we used neomycin to inhibit PLC activity. Neomycin inhibits the PLC pathway by binding phosphatidylinositols, thereby preventing the PLC-dependent generation of inositol trisphosphate and diacylglycerol $(50,51)$. While this reagent may not be the most effective or specific inhibitor of PLC pathways, it was selected based on the previous observation that it affected cholinergic influences on rat atrial contractility (21). Studies are presently underway using more selective and potent PLC inhibitors, to explore more fully the role of the PLC pathway in muscarinic-cholinergic signal transduction in the heart.

These observations show for the first time in an intact heart preparation that muscarinic cholinergic signal transduction in the heart via $G_{i}$ protein-dependent pathways is coupled not only to adenylyl cyclase but also to NOS. PT not only abolished cholinergic inhibition of $\beta$-adrenergic contractility but also led to a marked increase in NOS III protein abundance and activity. The latter novel observation supports a regulatory link between $\mathrm{G}_{\mathrm{i}}$ activity and NOS III expression.

\section{Acknowledgments}

The authors are indebted to Dr. Charles Lowenstein for generous assistance in Western blotting and wish to acknowledge the expert technical assistance of Koenraad Vandegaer and Townsend Barnett.

This work was supported by National Institutes of Health grant K08 HL03228 and a Grant-in-Aid from the American Heart Association (J.M. Hare).

\section{References}

1. Henning, R.J., I.R. Khalil, and M.N. Levy. 1990. Vagal stimulation attenuates sympathetic enhancement of left ventricular function. Am. J. Physiol. 258: H1470-H1475.

2. Kelly, R.A., J.-L. Balligand, and T.W. Smith. 1996. Nitric oxide and cardiac function. Circ. Res. 79:363-380.

3. Hare, J.M., J.F. Keaney, Jr., J.-L. Balligand, J. Loscalzo, T.W. Smith, and W.S. Colucci. 1995. Role of nitric oxide in parasympathetic modulation of $\beta$-adrenergic myocardial contractility in normal dogs. J. Clin. Invest. 95:360-366.
4. Balligand, J.-L., L. Kobzik, X. Han, D.M. Kaye, L. Belhassen, D.S. O'Hara, R.A. Kelly, T.W. Smith, and T. Michel. 1995. Nitric oxide-dependent parasympathetic signaling is due to activation of constitutive endothelial (type III) nitric oxide synthase in cardiac myocytes. J. Biol. Chem. 270:14582-14586.

5. Balligand, J.-L., R.A. Kelly, P.A. Marsden, T.W. Smith, and T. Michel 1993. Control of cardiac muscle cell function by an endogenous nitric oxide signaling system. Proc. Natl. Acad. Sci. USA. 90:347-351.

6. Mery, P., C. Pavoine, L. Belhassen, F. Pecker, and R. Fischmeister. 1993 Nitric oxide regulates cardiac $\mathrm{Ca}^{2+}$ current. J. Biol. Chem. 268:26286-26295.

7. Belhassen, L., R.A. Kelly, T.W. Smith, and J.-L. Balligand. 1996. Nitric oxide synthase (NOS3) and contractile responsiveness to adrenergic and cholinergic agonists in the heart. J. Clin. Invest. 97:1908-1915.

8. Balligand, J.-L., D. Ungureanu-Longois, W.W. Simmons, L. Kobzik, C.J. Lowenstein, S. Lamas, R.A. Kelly, T.W. Smith, and T. Michel. 1995. Induction of NO synthase in rat cardiac microvascular endothelial cells by IL-1 $\beta$ and IFN- $\gamma$. Am. J. Physiol. 268:H1293-H1303.

9. Han, X., Y. Shimoni, and W.R. Giles. 1994. An obligatory role for nitric oxide in autonomic control of mammalian heart rate. J. Physiol. 476:309-314.

10. Han, X., Y. Shimoni, and W.R. Giles. 1995. A cellular mechanism for nitric oxide-mediated cholinergic control of mammalian heart rate. J. Gen. Physiol. 106:45-65.

11. Levi, R.C., G. Alloatti, C. Penna, and M.P. Gallo. 1994. Guanylate-cyclasemediated inhibition of cardiac $\mathrm{I}_{\mathrm{Ca}}$ by carbachol and sodium nitroprusside. Pflugers Arch. 426:419-426.

12. Fleming, J.W., T.D. Hodges, and A.M. Watanabe. 1988. Pertussis toxintreated dog: a whole animal model of impaired inhibitory regulation of adenylate cyclase. Circ. Res. 62:992-1000.

13. Adamson, P.B., S.S. Hull, Jr., E. Vanoli, G.M. De Ferrari, P. Wisler, R.D. Foreman, A.M. Watanabe, and P.J. Schwartz. 1993. Pertussis toxin-induced ADP ribosylation of inhibitor $\mathrm{G}$ proteins alters vagal control of heart rate in vivo. Am. J. Physiol. 265:H734-H740.

14. Tucek, S., V. Dolezal, J. Folbergrova, S. Hynie, F. Kolar, and B. Ostadal. 1987. Pertussis toxin inhibits negative inotropic and negative chronotropic muscarinic cholinergic effects on the heart. Pflugers Arch. 408:167-172.

15. Boyer, J.L., M. Martinez-Carcamo, A. Monroy-Sanchez, J. JuarezAyala, G. Pastelin, C. Posadas, and J.A. Garcia-Sainz. 1986. Effect of pertussis toxin on the heart muscarinic-cholinergic receptors and their function. Life Sci. 39:603-610.

16. Neer, E.J. 1995. Heterotrimeric G proteins: organizers of transmembrane signals. Cell. 80:249-257.

17. Flavahan, N.A., H. Shimokawa, and P.M. Vanhoutte. 1991. Inhibition of endothelium-derived relaxations by phorbol myristate acetate in canine coronary arteries: role of a pertussis toxin-sensitive G-protein. J. Pharmacol. Exp. Ther. 256:50-55.

18. Miller, V.M., N.A. Flavahan, and P.M. Vanhoutte. 1991. Pertussis toxin reduces endothelium-dependent and independent responses to alpha-2 adrenergic stimulation in systemic canine arteries and veins. J. Pharmacol. Exp. Ther. 257:290-293.

19. Liao, J.K., and C.J. Homcy. 1993. The $G$ proteins of the $\mathrm{G}_{\alpha} \mathrm{i}$ and $\mathrm{G}_{\alpha} \mathrm{q}$ family couple the bradykinin receptor to the release of endothelium-derived relaxing factor. J. Clin. Invest. 92:2168-2172.

20. Kuchan, M.J., H. Jo, and J.A. Frangos. 1994. Role of G proteins in shear stress-mediated nitric oxide production by endothelial cells. Am. J. Physiol. 267:C753-C758.

21. Sterin-Borda, L., A.V. Echague, C.P. Leiros, A. Genaro, and E. Borda 1995. Endogenous nitric oxide signaling system and the cardiac muscarinic acetylcholine receptor-inotropic response. Br. J. Pharmacol. 115:1525-1531.

22. Weiss, R.G., C.P. de Albuquerque, K. Vandegaer, V.P. Chacko, and G. Gerstenblith. 1997. Attenuated glycogenolysis reduces glycolytic catabolite accumulation during ischemia in preconditioned rat hearts. Circ. Res. 79:435-446.

23. Goto, Y., B.K. Slinker, and M.M. LeWinter. 1991. Effect of coronary hyperemia on $\mathrm{E}_{\max }$ and oxygen consumption in blood-perfused rabbit hearts. Circ. Res. 68:482-492.

24. Keaney, J.F., Jr., J.M. Hare, R.A. Kelly, J. Loscalzo, T.W. Smith, and W.S. Colucci. 1996. Inhibition of nitric oxide synthase potentiates the positive inotropic response to $\beta$-adrenergic stimulation in normal dogs. Am. J. Physiol. 271:H2646-H2652.

25. Berger, H.-J., S.K. Prasad, A.J. Davidoff, D. Pimental, O. Ellingsen, J.D. Marsh, T.W. Smith, and R.A. Kelly. 1994. Continual electric field stimulation preserves contractile function of adult ventricular myocytes in primary culture. Am. J. Physiol. 266:H341-H349.

26. Kapadia, S.R., H. Oral, J. Lee, M. Nakano, G.E. Taffet, and D.L. Mann. 1997. Hemodynamic regulation of tumor necrosis factor- $\alpha$ gene and protein expression in adult feline myocardium. Circ. Res. 81:187-195.

27. Bredt, D., and S. Snyder. 1990. Isolation of nitric oxide synthase, a calmodulin-requiring enzyme. Proc. Natl. Acad. Sci. USA. 87:682-685.

28. Schulz, R., E. Nava, and S. Moncada. 1992. Induction and potential biological relevance of a $\mathrm{Ca}\left({ }^{2+}\right)$-independent nitric oxide synthase in the myocardium. Br. J. Pharmacol. 105:575-580.

29. Wallenstein, S., C. Zucker, and J. Fleiss. 1980. Some statistical methods useful in Circulation Research. Circ. Res. 47:1-9.

30. Hare, J.M., E. Loh, M.A. Creager, and W.S. Colucci. 1995. Nitric oxide 
inhibits the contractile response to $\beta$-adrenergic stimulation in humans with left ventricular dysfunction. Circulation. 92:2198-2203.

31. George, W.J., J.B. Polson, A.G. O'Toole, and N.D. Goldberg. 1970. Elevation of guanosine $3^{\prime}, 5^{\prime}$-cyclic phosphate in rat heart after perfusion with acetylcholine. Proc. Natl. Acad. Sci. USA. 66:398-403.

32. George, W.J., R.D. Wilkerson, and P.J. Kadowitz. 1973. Influence of acetylcholine on contractile force and cyclic nucleotide levels in the isolated perfused rat heart. J. Pharmacol. Exp. Ther. 184:228-235.

33. Krause, E., W. Halle, and A. Wollenberger. 1972. Effect of dibutyryl cyclic GMP on cultured beating rat heart cells. Adv. Cyclic Nucleotide Res. 1:301-305.

34. Shah, A.M., M.J. Lewis, and A.H. Henderson. 1991. Effects of 8-bromocyclic GMP on contraction and on inotropic response of ferret cardiac muscle. J. Mol. Cell. Cardiol. 23:55-64.

35. Watanabe, A.M., and H.R. Besch, Jr. 1975. Interaction between cyclic adenosine monophosphate and cyclic guanosine monophosphate in guinea pig ventricular myocardium. Circ. Res. 37:309-317.

36. Mery, P., S.M. Lohmann, U. Walter, and R. Fischmeister. 1991. Ca ${ }^{2+}$ current is regulated by cyclic GMP-dependent protein kinase in mammalian cardiac myocytes. Proc. Natl. Acad. Sci. USA. 88:1197-1201.

37. Hartzell, H.C., and R. Fischmeister. 1986. Opposite effects of cyclic GMP and cyclic AMP on $\mathrm{Ca}^{2+}$ current in single heart cells. Nature. 323:273-275.

38. Shah, A.M., H.A. Spurgeon, S.J. Sollott, A. Talo, and E.G. Lakatta. 1994. 8-bromo-cGMP reduces the myofilament response to $\mathrm{Ca}^{2+}$ in intact cardiac myocytes. Circ. Res. 74:970-978.

39. Freeman, J.E., IV, W.Y. Kuo, G. Milligan, C.J. Lowenstein, M.A. Levine, and N.A. Flavahan. 1995. Analysis of pertussis toxin-sensitive receptor: G-protein interactions in native porcine endothelial cells. Endothelium. 3:321330.

40. Liao, J.K., and C.J. Homcy. 1993. The release of endothelium-derived relaxing factor via $\alpha_{2}$-adrenergic receptor activation is specifically mediated by $\mathrm{G}_{i} \alpha 2$. J. Biol. Chem. 268:19528-19533.

41. Liao, J.K., and C.J. Homcy. 1992. Specific receptor-guanine nucleotide binding protein interaction mediates the release of endothelium-derived relax- ing factor. Circ. Res. 70:1018-1026.

42. Liao, J.K. 1994. Inhibition of $\mathrm{G}_{\mathrm{i}}$ proteins by low density lipoprotein attenuates bradykinin-stimulated release of endothelial-derived nitric oxide. $J$ Biol. Chem. 269:12987-12992.

43. Feron, O., T.W. Smith, T. Michel, and R.A. Kelly. 1997. Dynamic targeting of the agonist-stimulated $\mathrm{m} 2$ muscarinic acetylcholine receptor to caveolae in cardiac myocytes. J. Biol. Chem. 272:17744-17748.

44. Fleming, J.W., P.L. Wisler, and A.M. Watanabe. 1992. Signal transduction by $\mathrm{G}$ proteins in cardiac tissues. Circulation. 85:420-433.

45. Ayajiki, K., M. Kindermann, M. Hecker, I. Fleming, and R. Busse. 1996. Intracellular $\mathrm{pH}$ and tyrosine phosphorylation but not calcium determine shear stress-induced nitric oxide production in native endothelial cells. Circ. Res. 78: $750-758$.

46. Stamler, J.S., E. Loh, M. Roddy, K.E. Currie, and M.A. Creager. 1994. Nitric oxide regulates basal systemic and pulmonary vascular resistance in healthy humans. Circulation. 89:2035-2040.

47. Klabunde, R.E., R.C. Ritger, and M.C. Helgren. 1991. Cardiovascular actions of inhibitors of endothelium-derived relaxing factor (nitric oxide) formation/release in anesthetized dogs. Eur. J. Pharmacol. 199:51-59.

48. Kojda, G., K. Kottenberg, P. Nix, K.D. Schluter, H.M. Piper, and E. Noack. 1996. Low increase in cGMP induced by organic nitrates and nitrovasodilators improves contractile response of rat ventricular myocytes. Circ. Res. 78:91-101.

49. Campbell, D.L., J.S. Stamler, and H.C. Strauss. 1996. Redox modulation of L-type calcium channels in ferret ventricular myocytes. Dual mechanism regulation by nitric oxide and $S$-nitrosothiols. J. Gen. Physiol. 108:277-293.

50. Cockcroft, S., and B.D. Gomperts. 1985. Role of guanine nucleotide binding protein in the activation of polyphosphoinositide phosphodiesterase. Nature. 314:534-536.

51. Vitale, N., D. Thierse, D. Aunis, and M.-F. Bader. 1993. Exocytosis in chromaffin cells: evidence for a MgATP-independent step that requires a pertussis toxin-sensitive GTP-binding protein. Biochem. J. 300:217-227. 